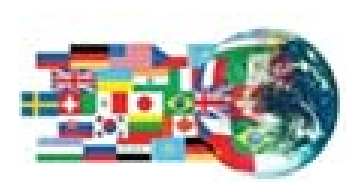

Pacific Northwest Center for

Global Security

\title{
Industry Self-Regulation as a Means To Promote Nonproliferation
}

October 2005

Gretchen Hund, Senior Staff Scientist Oksana Elkhamri, Research Scientist 


\title{
DISCLAIMER
}

This report was prepared as an account of work sponsored by an agency of the United States Government. Neither the United States Government nor any agency thereof, nor Battelle Memorial Institute, nor any of their employees, makes any warranty, express or implied, or assumes any legal liability or responsibility for the accuracy, completeness, or usefulness of any information, apparatus, product, or process disclosed, or represents that its use would not infringe privately owned rights. Reference herein to any specific commercial product, process, or service by trade name, trademark, manufacturer, or otherwise does not necessarily constitute or imply its endorsement, recommendation, or favoring by the United States Government or any agency thereof, or Battelle Memorial Institute. The views and opinions of authors expressed herein do not necessarily state or reflect those of the United States Government or any agency thereof.

\author{
PACIFIC NORTHWEST NATIONAL LABORATORY \\ operated by \\ BATTELLE \\ for the \\ UNITED STATES DEPARTMENT OF ENERGY \\ under Contract DE-AC05-76RL01830
}

Printed in the United States of America
Available to DOE and DOE contractors from the Office of Scientific and Technical Information,
P.O. Box 62, Oak Ridge, TN 37831-0062;
ph: (865) 576-8401
fax: $(865)$ 576-5728
email: reports@adonis.osti.gov

\begin{abstract}
Available to the public from the National Technical Information Service, U.S. Department of Commerce, 5285 Port Royal Rd., Springfield, VA 22161 ph: (800) 553-6847 fax: $(703) 605-6900$ email: orders@ntis.fedworld.gov online ordering: http://www.ntis.gov/ordering.htm
\end{abstract}

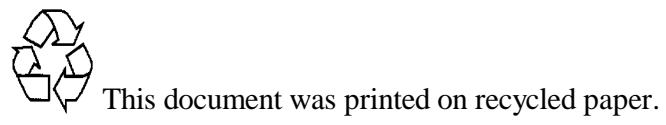




\subsection{Objectives}

This analysis proposes a continuum of self-regulation approaches for the nuclear, radiological sources and other dual-use industries to consider as a means of combating proliferation of weapons of mass destruction. It specifically targets the aforementioned industries in the area of export control and physical protection of individual industry's facilities and material. ${ }^{1}$ The paper analyzes several cases of different industries that implemented a self-regulation approach and extracts lessons learned from these cases.

The need for a self-regulation approach among the aforementioned industries results from the nexus between terrorism and nuclear proliferation. The terrorist attacks of 9/11, AQ Khan illicit nuclear trade networks and the prerogatives put forward by President Bush in his February 2004 speech, and IAEA Director General, Mohamed Elbaradei's calls for an increased role of the nuclear industry in combating nuclear proliferation serve as triggers for this analysis and proposition. Another motivating factor for creating such an industry organization / program is UNSC Resolution 1540 that calls “...upon all States to...Develop appropriate ways to work with and inform industry and the public regarding their obligations under such laws...” Such pressing need for industry's proactive engagement in combating proliferation includes industry improving its compliance with export control regulations. A recent survey on U.S. Industry ${ }^{2}$ Compliance $^{2}$ and Export Control conducted by the Center of International Trade and Security at the University of Georgia, revealed that out of 120 surveyed companies, nearly 54\% of the companies had selfreported violations and nearly $27 \%$ had received a warning letter from the US government about violations. ${ }^{3}$ More than $81 \%$ of the respondents contend that lack of knowledge about export controls was the "most important" or an "important" cause of violations. Overall, industry scored a "C" (76 out of a 100 possible) on an index of "best practices" for export control compliance. ${ }^{4}$ Awareness of these shortcomings is the first step in encouraging industry to take a proactive role in improving its compliance with a knowledge of combating proliferation of WMDs.

Furthermore, the cost of compliance programs by individual companies is not trivial. The survey found that on average export compliance systems are costly, particularly for smaller exporters that have seen a $340 \%$ cost increase from $1985 .{ }^{5}$ Great savings could likely be gained by having

\footnotetext{
${ }^{1}$ Nuclear, radiological sources and other dual-use industries generally have some sensitive material, facilities or sources/components that could be coveted by terrorists or profiteers. A self-regulation approach for physical protection of these items would help prevent them from getting on the black market and could potentially create an effective way of securing sensitive items at the source of their design, production, and/or distribution. Note that this paper defines "nuclear" exports as meaning trigger list items that are specified in Part 1 of the Nuclear Suppliers Group guidelines (IAEA INFCIRC/254/Rev.6/Part 1, May 2003). "Dual-use" exports refer to items that are specified in Part 2 of the Nuclear Suppliers Group guidelines; such exporters include a large range of industries (INFCIRC/254/Rev. 5/Part 2, May 2003).

${ }^{2}$ The industry surveyed included 120 leading US exporters of strategic munitions and dual-use items. The survey recognizes that this sample of companies is not representative of the universe of more than 200,000 US exporters and that these companies are likely to have much higher standards of compliance than the average, making the statistics even more alarming.

${ }^{3}$ Center for International Trade and Security,"Survey on U.S. Industry Compliance and Export Controls: Executive Summary,”,School of Public and International Affairs, University of Georgia, August 16, 2005, http://www.uga.edu/cits/documents/html/us_industry_compliance.htm

${ }^{4}$ Ibid.

${ }^{5}$ Ibid.
} 
an industry-wide organization provide support in this area. This paper outlines a range of selfregulation approaches for industry to consider.

\subsection{Overview}

Several industries have created organizations to promote self-regulation as a means of encouraging best practices among companies within the industry. The proposition of this study is that the nuclear industry has had a history of self-policing and remains in an excellent position to monitor itself (in addition to the standard regulations that government oversees and enforces). A proactive self-regulation approach helps industries identify problems early on, address them in a proper manner without damaging consequences, and consequently grow their business. Any one company within an industry that behaves poorly reflects negatively on the entire industry. The Bhopal disaster in India is an excellent example of this and the chemical industry's creation of Responsible Care.

This paper describes several case studies of industry self-regulation, as a means of determining what lessons learned may be applicable to the nuclear, radiological sources, and dual use industries to stem illicit trade activities and unauthorized transfers. Furthermore, a straw position is presented on what the self-regulation approach could look like. There are two components to this approach: one focuses on export control as a means of combating illicit nuclear trade activities; the other focuses on the physical protection of nuclear materials on site of an industry's facility. Possible incentives and disincentives for these industries to participate are also presented.

\subsection{Industry Self-Regulation Case Studies}

To understand better the drivers and processes behind self-regulation, the team has reviewed four specific industry cases where different industries have adopted self-regulation as an approach: Diamond, Fertilizer, Cement, and Chemical. Appendix A (Table 1-4) describes in detail the selfregulation approach used in each case, the implementing entity, the incentives for industry to join, the disincentives to join, and some comments on operational issues of the organization or program that is in place. It also lists whether the industry cases are export control related or physical protection of materials related and describes the incident or triggering event that caused the industry to establish an industry-wide organization (generally in the form of an NGO) to monitor activities and encourage best practices. ${ }^{6}$ The missions of these organizations range from establishing a code of conduct or ethics to setting an enforceable standard that all participants must follow (and in some cases is audited by a third-party). In other cases, affiliate organizations are partnered with the industry organization. Table 1 is a summary of the four cases reviewed. For each case the industry implementing the self-regulation approach is listed, the program is named, and the institutional approach implemented is provided.

\footnotetext{
${ }^{6}$ The majority of industries reviewed have used an existing implementing entity (NGOs usually) to establish new programs to implement a self-regulation approach. Only in one case (the cement industry) did industry establish a new implementation entity and a new program.
} 
Table 1-Summary of I mplementation Process for Reviewed I ndustries

\begin{tabular}{|c|c|c|c|}
\hline I ndustry & $\begin{array}{l}\text { Industry } \\
\text { I mplementing } \\
\text { Entity }\end{array}$ & Program & Approach \\
\hline \multirow[t]{2}{*}{ Diamond } & Existing & New & \multirow{2}{*}{$\begin{array}{l}\text { Joint government, international industry and civil society } \\
\text { initiative } \\
\text { Countries are charged with enforcement but the NGO and civil } \\
\text { society groups contribute to the effective implementation and } \\
\text { monitoring of the program. }\end{array}$} \\
\hline & $\begin{array}{l}\text { World Diamond Council } \\
\text { (NGO) }\end{array}$ & $\begin{array}{l}\text { Kimberley Process Certification } \\
\text { Scheme }\end{array}$ & \\
\hline \multirow[t]{4}{*}{ Fertilizer } & Existing & New & \multirow{4}{*}{$\begin{array}{l}\text { Private (NGO)/ public partnership where they agree on safety } \\
\text { measures. }\end{array}$} \\
\hline & $\begin{array}{l}3 \text { NGOs: European Fertilizer } \\
\text { Manufacturers Association } \\
\text { (EFMA); }\end{array}$ & \multirow[t]{2}{*}{ “Product Stewardship” } & \\
\hline & $\begin{array}{l}\text { International Fertilizer } \\
\text { Industry Association (IFA); }\end{array}$ & & \\
\hline & $\begin{array}{l}\text { The Fertilizer Institute } \\
\text { (TFA) }\end{array}$ & $\begin{array}{l}\text { “America’s Security Begins } \\
\text { with You” }\end{array}$ & \\
\hline \multirow[t]{2}{*}{ Cement } & \begin{tabular}{l|l} 
New & \\
\end{tabular} & New & \multirow{2}{*}{$\begin{array}{l}\text { Completely industry based but initially with advice from } \\
\text { independent NGOs and an advisory council of outsiders who are } \\
\text { still somewhat involved. }\end{array}$} \\
\hline & $\begin{array}{l}\text { NGO: } 16 \text { companies make } \\
\text { up the initiative }\end{array}$ & $\begin{array}{l}\text { Cement Industry Sustainability } \\
\text { Initiative }\end{array}$ & \\
\hline \multirow[t]{2}{*}{ Chemical } & Existing & New & \multirow[b]{2}{*}{ Unilateral Agreement among members of the NGO. } \\
\hline & $\begin{array}{l}\text { International Council of } \\
\text { Chemical Associations } \\
\text { (formerly known as } \\
\text { Chemical Manufacturers } \\
\text { Association) }\end{array}$ & Responsible Care & \\
\hline
\end{tabular}


The underlying trigger for the Diamond Industry case study was public outcry. Diamonds were being sold by rebel movements to finance wars against legitimate governments. The UN Security Council passed resolutions against the purchase of these "conflict" diamonds but the industry ignored them by claiming ignorance. International media broadcasted the results of the "Global Witness" report and the public's outrage caused the UN to pass resolutions that called upon the industry to independently establish a certification process to track all diamond purchases. Therefore, in this case the industry formed its own certification program (called the Kimberley Process Certification Scheme) using the approach of a joint government, international industry and civil society initiative to stem the flow of conflict diamonds. The industry implementing entity was/is the World Diamond Council (WDC) but in combination with governments that enforce it and civil society groups that help to monitor implementation and effectiveness. Individual companies had to implement the Kimberley Process if they were stay in business. Much more detail is provided in Appendix A, Table $1 .^{7}$

The Fertilizer Industry's triggering events for establishing a self-regulation approach were the bombings that occurred where ammonium nitrate was used as the bomb fuel (e.g., Oklahoma City federal building, Bali night club, World Trade center attack). This industry has three NGOs (international one, European one, and institute). The mission of each is somewhat different and the most relevant is The Fertilizer Institute that established the "American's Security Begins with You” campaign in 2004. However, even the European Fertilizer Manufacturers Association is interested in stricter safety regulations. The approach used with this industry was a private (NGO) / public partnership to establish safety measures regarding ammonium nitrate. The incentives to join these NGOs are numerous ranging from having access to the latest information on safety benchmarking and new technology, having close ties with government officials who influence regulations, working together to influence policy for the entire industry, easily running background checks and allowing only those who run legitimate businesses to sell, purchase, and transport fertilizer. Disincentives include loosing independent decision making and having less influence if you are a small company. The industry feels that they have gained significant public support and more business by taking this proactive step. Again, more detail in presented in Appendix A, Table $2 .^{8}$

The third case, the Cement Industry, is unusual in that it went to a completely separate entity an NGO called the World Business Council for Sustainable Development (WBCSD), to seek advice and council on how to manage their $\mathrm{CO}_{2}$ emissions and other factors associated with their operations. The industry knew it was one of the greatest industry emitters of $\mathrm{CO}_{2}$ and wanted to be proactive in evaluating options given global climate change discussions. The WBCSD hired Battelle to conduct the analysis. ${ }^{9}$ All of the reporting has been transparent. The industry "they" started out as a few leaders and grew into a group of 16 today that represent two-thirds of the world's production of cement outside of China. There is no government regulation forcing them to better police their operations. There have been numerous incentives for companies to join the

\footnotetext{
${ }^{7}$ Chidester, Robert C., "Self-Regulation within the Diamond Industry: Case Study with a Focus on the Kimberley Process and Conflict Diamonds," case study commissioned by PNNL, June 2005.

${ }^{8}$ Wyman, Charles, "Self-Regulation within the Fertilizer Industry: Focusing on Ammonium Nitrate Regulations," case study commissioned by PNNL, June 2005.

${ }^{9}$ All WBCSD reports, including Battelle’s study, can be accessed from www.wbcsdcement./final_reports.asp
} 
Initiative, including speaking with one voice to all their stakeholders to stress their commitment to sustainable development principles (including having several reporting requirements on environmental conditions, public health and worker health and safety, and business performance). Among other requirements, participants of this initiative must publish a statement of business ethics, and develop documented and auditable environmental management systems at all their plants. Disincentives to join the Initiative include the complexity of coordinating and building consensus across global companies and a loss of independent decision making, particularly for some of the smaller companies with less of a voice. However, from interviews conducted with industry representatives, it appears that participants are overall quite pleased with the outcomes from this effort. They feel that they have improved in all areas of sustainable development. ${ }^{10}$ Refer to Table 3 in Appendix A for more detail.

The fourth case is the Chemical Industry, which is likely the best known of the self-regulation cases reported. Bhopal was a horrific accident that shook the industry. The existing Chemical Manufacturers Association ${ }^{11}$ created Responsible Care in 1985, following the accident, to address concerns about the manufacture, distribution, and use of chemicals. Member companies were (and are) required to implement Responsible Care. Companies that together produce over $85 \%$ of all chemicals worldwide (from 46 countries) are members of what is now the International Council of Chemical Associations. ${ }^{12}$ Benefits from the program included sharing of best practices that resulted in process improvements and cost reductions, pre-empting threatened regulations, influencing inevitable regulations, avoiding consumer boycotts, and deflecting monitoring and enforcement. Through sharing of information and a rigorous system of checklists, performance indicators and verification procedures, this industry can demonstrate how it has improved its operations including exports. Individual countries' Responsible Care programs are at different stages of development and have different emphases but are monitored and coordinated by the ICCA. ${ }^{13}$

James Miller, the former Chairman of the FTC has been quoted saying that "Self regulation directly involves the parties who will generally have the best institutional knowledge about the need for action and about the efficacy of various potential actions. Second, self regulation is more flexible, and therefore is less likely to stifle innovation or excessively limit consumer choice."14 Self regulation is not an end in itself, but combined with necessary government regulations can improve overall performance of the parties.

\subsection{Proposed Self-Regulation Approach for Export and Physical Security of Materials}

There are several possibilities for instituting a self-regulation approach for the nuclear, radiological sources, and dual-use industries. For the nuclear industry, one of the existing nuclear NGOs could be approached to determine its interest in this mission (see Appendix B for

\footnotetext{
10 The author, Gretchen Hund, participated in this three-year Battelle study for the WBCSD.

${ }^{11}$ CMA changed its name to the International Council of Chemical Associations.

12 The website for the ICCA is www.ICCA-chem.org.

13 Ibid.

${ }^{14}$ Miller, James, “The FTC and Voluntary Standards: Maximizing the Net Benefits of Self-Regulation.” White House Conference on Association Self Regulation, Washington, DC, Oct. 3, 1984.
} 
a full description of these NGOs). Given that the need is to regulate the whole nuclear fuel cycle, with greatest concerns around enrichment and reprocessing, some partnership of existing NGOs might be necessary to address the need. A first step in vetting the concept may be to meet with a few nuclear industry leaders to determine their interest in a self-regulation program. ${ }^{15}$ For the radiological sources industry, there is no one NGO given the various applications of sources. It may be possible to leverage existing industry organizations for the most prevalent use of sealed sources (e.g., medical imaging and well-logging) to determine their interest in such a program. ${ }^{16}$ The most difficult "industry" to investigate is the dual-use "industries" because of the diversity. Again, individual industries, such as lasers, may have industry organizations that could be approached. Table 2 outlines a number of incentives and disincentives for the nuclear, radiological, and dual-use industries to participate in such a program.

\footnotetext{
${ }^{15}$ Gretchen Hund attended the World Nuclear Association Annual Conference in London, September 7-9, 2005 and spoke with nuclear energy industry representatives to determine their interest in nonproliferation. She found interest in the topic but found no one who could recommend a single NGO as the right entity to actively promote nonproliferation. The existing NGOs are focused on promoting nuclear energy and/or safety associated with plant operations, but not security. Please refer to Appendix B Table 1 with more detail on nuclear industry NGOs.

${ }^{16}$ Initial discussions have begun with representatives of the well-logging industry and there is interest on their part.
} 
Table 2-Possible I mplementation Process for Nuclear, Radiological Source, and Dual-Use I ndustries

\begin{tabular}{|c|c|c|c|c|c|}
\hline Industry & Triggering Event & $\begin{array}{l}\text { I mplementing } \\
\text { Entity / } \\
\text { Approach }\end{array}$ & I ncentives to J oin & Challenges & Comments \\
\hline $\begin{array}{l}\text { Nuclear: } \\
\text { Nuclear } \\
\text { Manufacturers } \\
\text { Nuclear Services }\end{array}$ & $\begin{array}{l}\text { President's speech of } \\
\text { February } 2004 \\
\text { Events of 9/11 } \\
\text { AQ Khan Illicit Networks } \\
\text { Elbaradei's call for } \\
\text { industry to combat } \\
\text { proliferation }\end{array}$ & $\begin{array}{l}\text { Private (NGOs) / public } \\
\text { partnership (e.g., some } \\
\text { existing or new NGO } \\
\text { with govt. entities such } \\
\text { as DOC and DOE in the } \\
\text { US). }{ }^{17}\end{array}$ & \multirow{3}{*}{$\begin{array}{l}\text { 1. Sharing of industry best practices in } \\
\text { both export control and physical } \\
\text { security of materials resulting in } \\
\text { procedural improvements and } \\
\text { potential cost reductions } \\
\text { 2. Making training available on best } \\
\text { practices } \\
\text { 3. Using the industry organization as a } \\
\text { united, common voice for industry's } \\
\text { relevant positions with international } \\
\text { regulatory bodies, such as the IAEA, } \\
\text { and with national regulatory bodies } \\
\text { across participating states. Establish } \\
\text { close ties with government officials } \\
\text { who influence and implement relevant } \\
\text { regulations } \\
\text { 4. Members of the industry entity would } \\
\text { have an advantage in selling their } \\
\text { products over their competitors who } \\
\text { are not members. Perhaps a "Green } \\
\text { Lane” or something equivalent could } \\
\text { be created for members with pre- } \\
\text { approved exports to accelerate the } \\
\text { paperwork of shipments } \\
\text { 5. By creating such an entity and } \\
\text { following a strong Code of Conduct, } \\
\text { further government intervention could } \\
\text { be minimized } \\
\text { 6. Could play favorably in a company’s } \\
\text { ability to obtain an export license from } \\
\text { NRC for source-using industries } \\
\text { (radiological sources) }\end{array}$} & $\begin{array}{l}\text { Developing an entity } \\
\text { that is workable at } \\
\text { the international level } \\
\text { and at the working- } \\
\text { on-the-ground level } \\
\text { and ensuring that } \\
\text { communication is } \\
\text { occurring across } \\
\text { these levels. } \\
\text { Coordinating } \\
\text { industry's interests } \\
\text { with governments' } \\
\text { interests will also be } \\
\text { necessary. }\end{array}$ & $\begin{array}{l}\text { This initiative could be } \\
\text { started within industry } \\
\text { initially and then broadened } \\
\text { to include governments. } \\
\text { Companies who have } \\
\text { requested trigger list licenses } \\
\text { could initiative the effort. }\end{array}$ \\
\hline $\begin{array}{l}\text { Radiological } \\
\text { Source }\end{array}$ & $\begin{array}{l}\text { President's speech of } \\
\text { February } 2004 \\
\text { Events of } 9 / 11 \\
\text { Dirty bomb threat }\end{array}$ & $\begin{array}{l}\text { Private (NGO) / public } \\
\text { partnership, industry- } \\
\text { specific (e.g., well- } \\
\text { loggers, medical } \\
\text { imaging) with govt. } \\
\text { entities such as NRC in } \\
\text { the US. }\end{array}$ & & $\begin{array}{l}\text { Will need to work } \\
\text { this through } \\
\text { individual industries. } \\
\text { Need to identify } \\
\text { relevant professional } \\
\text { organizations that } \\
\text { could be leveraged. }\end{array}$ & $\begin{array}{l}\text { Large companies within an } \\
\text { industry (e.g., well loggers) } \\
\text { that routinely request } \\
\text { licenses from NRC could be } \\
\text { approached first. }\end{array}$ \\
\hline Dual-Use & $\begin{array}{l}\text { President's speech of } \\
\text { February } 2004 \\
\text { Events of 9/11 } \\
\text { AQ Khan Illicit Networks }\end{array}$ & $\begin{array}{l}\text { Private (NGO) / public } \\
\text { partnership, industry } \\
\text { specific (e.g., lasers) } \\
\text { with govt. entities such } \\
\text { as DOC, NRC, and } \\
\text { DOE in the US. }\end{array}$ & & $\begin{array}{l}\text { The diversity of } \\
\text { industries in this } \\
\text { category could make } \\
\text { this very challenging. }\end{array}$ & $\begin{array}{l}\text { May want to start with the } \\
\text { above two industries before } \\
\text { starting this initiative. Dual- } \\
\text { use industry could develop } \\
\text { guidance via an ISO } \\
\text { standard that is applicable to } \\
\text { a range of dual-use } \\
\text { companies. }\end{array}$ \\
\hline
\end{tabular}

\footnotetext{
${ }^{17}$ See Appendix B with detailed information of the various existing nuclear NGOs and what incentives they may have to establish a self-regulation program. It may, however, be necessary for a new NGO to be established that would promote this agenda.
} 
The nuclear, radiological sources, and dual-use industries can take many different approaches in implementing a self-regulation program. The approaches are not mutually exclusive, not comprehensive, and generally expand from easier to implement to more difficult to implement (possibly short-term to more long-term options). The continuum in Figure 1 displays a possible range of options that these industries could pursue.

Figure 1 -Continuum of Industry Self-Regulation Approaches

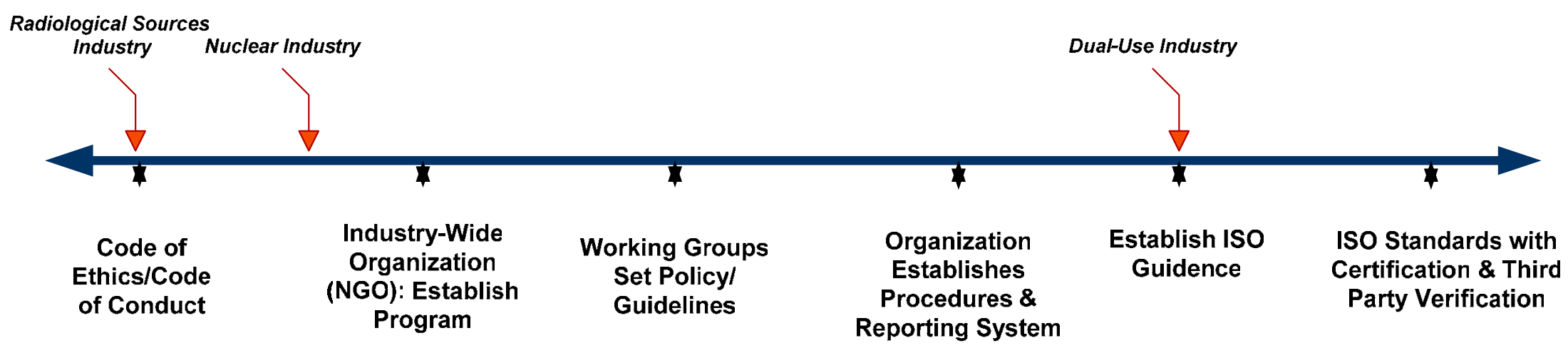

The options range from the easier to implement such as Code of Conduct or Ethics that could serve as an ethical guidance around export control and protection of sensitive commodities on site to a more sophisticated approach involving a formalized system of governance and institutionalized procedures and accountability. Initially, the industry could establish the easiest to implement (e.g., Code of Conduct or Ethics) and eventually opt to move to the right on the continuum and implement a more enforceable structure, with explicit procedures, reporting mechanisms ${ }^{18}$, internal auditing, and certification ${ }^{19}$ with third party verification. With respect to

\footnotetext{
${ }^{18}$ Such reporting could be structured similarly to several sustainable development reporting initiatives, which have the aim to facilitate comparison among different companies' reports. First is the Global Reporting Initiative (GRI), which provides a framework for company reporting that allows easy comparison within and across a variety of organizations for voluntarily reporting on sustainable activities. Its website is www.globalreporting.org. Another reporting initiative is the Public Environmental Reporting Initiative (PERI). The PERI framework contains key components for environmental reporting for all types of organizations, with the aim of assisting them to create balanced and comparable reports that can be measured over time. Information on PERI can be found on the International Chamber of Commerce's website www.iccwbo.org. Also IBM describes PERI through the following website -

www.ibm.com/ibm/environment/initiatives/peri.phtml. Finally, the last such initiative is SustainAbility/UNEP Engaging Stakeholders Initiative. This focuses on all sectors and aims to measure success in corporate environmental, social or sustainability reporting and significantly to boost reporting by companies. Its website is www.unepie.org/outreach/reporting/sustainability.htm.
} 
export control, a specific option is that the industry organization could establish a clearinghouse on export recipients that could help "green lane" exports to approved recipients. This database could be shared with relevant government bodies in some form of a partnership as a means to showcase the industry's transparency and commitment. As illustrated in Table 2, government partnership will likely further the programs' impact and can be included to varying levels of degree along the entire continuum. It must be noted that guidance via an ISO standard may be an appealing approach for dual-use industry, given the diversity of industries that fall into this category. Participants developing the standard could come from a range of industries to ensure it is comprehensive. This standard may not be a certification standard, but it could still be helpful in encouraging industry to take a more proactive stance on combating black market activities.

As mentioned with respect to the nuclear industry, a number of companies could serve as potential participants and advocates of the self-regulation approach. While it is not clear as to what specific companies would be best to initiate the process, the companies that manufacture and sell trigger-list nuclear items and that have requested a license for their export could serve as the potential proponents of the self-regulation model. The following list is of companies that have requested such a license from the NRC is the last couple of years. They would likely be a good group with whom to initiate discussions.

1) COGEMA (including Duke, Stone, and Webster)

2) ConverDyn

3) Edlow International Company

4) Exelon Generation LLC

5) Framatome ANP

6) GE Energy

7) Mitsui \& Co Ltd

8) NAC International

9) RSB Logistic GmbH (but North America subsidiary)

10) RWE NUKEM GmbH

11) Sojitz Corporation

12) Transport Logistics Inc.

13) Urenco Ltd.

14) USEC Inc.

15) Westinghouse Electrical

The NGO, the Nuclear Threat Initiative (NTI), has been advocating improved global physical security of weapons-usable nuclear materials. Charles Curtis from NTI made a presentation at the recent INMM annual meeting (July 11, 2005) on "promoting global best

\footnotetext{
${ }^{19}$ ISO was the entity used to create a self-regulation program for industries concerned about improving environmental performance. ISO 14001 has organizations create environmental management systems to track and report on environmental performance. www.iso14000.org.
} 
practices" focusing on the physical security of nuclear materials. ${ }^{20}$ He challenged industry to formulate best practices for safeguarding nuclear materials, to communicate them broadly, and put them into practice worldwide. He proposed INMM as a possible vehicle to developing an organization to promote voluntarily measures to improve nuclear materials security. ${ }^{21}$

The proposal here is to combine physical security of materials at industries' facilities with better export controls. INMM is a professional society, not a company membership organization, and therefore may lack the strong operational practice necessary to serve as a stand-alone organization for promoting this self-regulation. It may be a good advocate, however, for creating some type of entity to assume this mission. The World Nuclear Association (WNA) is an alternative organization, but based on industry representative feedback from some discussions during WNA's annual conference this year ${ }^{22}$, nonproliferation is likely outside of its mission. The World Association of Nuclear Operators (WANO) is another industry organization. However, Mr. Lucas Mampaey, WANO's Managing Director, responded at the WNA annual meeting that broadening his organization's mission from safety to include security would be a stretch. He saw the need for industry to promote nonproliferation, but could not identify the most appropriate industry entity to take the lead. ${ }^{23}$ Industry leaders with an interest in export control and physical protection of materials at their facilities may need to take the initiative to establish some type of program. ${ }^{24}$ A new industry NGO could potentially grow out of this initiative. Again, partnerships could be formed with government entities to ensure that the program is robust. Smaller, industryworking groups also could be approached to determine their interest. For example, in terms of the physical security of materials component, nuclear power reactor Owners Groups could be approached. Soliciting input from individuals representing organizations with a broad perspective along with individuals with a "working on-the-ground-level" perspective would likely improve the framing of an industry organization that would best meet the needs to ensure that goods and services are well controlled and managed to combat black market activities.

\footnotetext{
${ }^{20}$ Curtis, Charles B., “Promoting Global Best Practices”, presented at the Institute for Nuclear Materials Management $46^{\text {th }}$ Annual Meeting, Phoenix, AZ, July $11,2005$.

21 Ibid.

${ }^{22}$ Gretchen Hund attended the World Nuclear Association Annual Conference in London, September 7-9, 2005 and spoke with several WNA members to determine their interest in nonproliferation. They saw the need but felt that it was outside of WNA's mission. Appendix A, Table 2 lists WNA's Charter of Ethics that does include nonproliferation language.

${ }^{23}$ Gretchen Hund had this discussion with Mr. Mampaey at the WNA annual conference on September 8, 2005.

${ }^{24}$ See the range of approaches listed in Figure 1.
} 


\section{APPENDIX A}

TABLE 1-Diamond I ndustry Self-Regulation Approach

\begin{tabular}{|c|c|c|c|c|c|}
\hline Industry & Triggering Event/Context & Implementing Entity & $\begin{array}{c}\text { Incentives to } \\
\text { Join }\end{array}$ & $\begin{array}{c}\text { Disincentives } \\
\text { to Join }\end{array}$ & Comments \\
\hline $\begin{array}{l}\text { Diamonds }{ }^{25} \text { - } \\
\text { (Export Control } \\
\text { Example) } \\
\text { World Diamond } \\
\text { Council (WDC)_- } \\
\text { corporations that } \\
\text { purchase and sell } \\
\text { diamonds and } \\
\text { countries that host } \\
\text { them. } \\
\text { The role of the } \\
\text { Kimberley Process } \\
\text { (KP) is to stem the } \\
\text { flow of conflict } \\
\text { diamonds. The KP } \\
\text { Certification } \\
\text { Scheme is an } \\
\text { innovative, } \\
\text { voluntary system } \\
\text { that imposes } \\
\text { extensive } \\
\text { requirements on } \\
\text { participants to } \\
\text { certify shipments of } \\
\text { diamonds. }\end{array}$ & $\begin{array}{l}\text { International community alerted UN of } \\
\text { human rights violations in Africa and } \\
\text { exposed rebel groups funded by the } \\
\text { unregulated sale of diamonds. UN } \\
\text { responded by referring the issue to the } \\
\text { Security Council which passed } \\
\text { resolutions that were a series of } \\
\text { embargoes and sanctions against the } \\
\text { purchase of diamonds from these } \\
\text { organizations. BUT the diamond } \\
\text { industry circumvented them by } \\
\text { claiming ignorance. International media } \\
\text { broadcasted the results of the "Global } \\
\text { Witness” report and the public's } \\
\text { outrage caused the UN's General } \\
\text { Assembly to pass Resolutions 55/56 } \\
\text { under Section VI of their charter in } \\
\text { 2000- called upon the diamond } \\
\text { industry and their host countries to } \\
\text { independently establish a certification } \\
\text { process to track all diamond purchases. } \\
\text { The industry was worried about being } \\
\text { the next fur industry and shunned. } \\
\text { In 2002, the WDC, in response to the } \\
\text { UNs resolutions, adopted the KP, } \\
\text { which was codified by the UN Security } \\
\text { Council in resolution } 1459 \text {. }\end{array}$ & $\begin{array}{l}\text { The Kimberley Process Certification } \\
\text { Scheme (KPCS) is a joint } \\
\text { government, international diamond } \\
\text { industry (WDC) and civil society } \\
\text { (e.g., Global Witness \& Partnership } \\
\text { Africa Canada) initiative. } \\
\text { NGO (WDC) is industry's entity that } \\
\text { implements the Kimberley Process -- } \\
\text { "Each participating country is } \\
\text { required to ensure that all shipments } \\
\text { of rough diamonds exported to or } \\
\text { imported from a participant country } \\
\text { are accompanied with a duly } \\
\text { validated certificate and shall ensure } \\
\text { that no shipments of rough diamonds } \\
\text { are imported from or exported to a } \\
\text { non-participant. “26 } \\
\text { Members are NOT to "buy diamonds } \\
\text { from firms that lack the KPCS on } \\
\text { their invoices; nor buy any diamonds } \\
\text { from suspect or unknown sources of } \\
\text { supply and/or that originate in } \\
\text { countries that have not implemented } \\
\text { the KP; nor buy diamonds from any } \\
\text { conflict region; nor buy or sell or } \\
\text { assist others to buy or sell conflict } \\
\text { diamonds.”27 }\end{array}$ & $\begin{array}{l}\text { Public demand } \\
\text { that retailers } \\
\text { only sell } \\
\text { certified } \\
\text { diamonds. } \\
\text { Few retailers } \\
\text { would risk } \\
\text { being caught } \\
\text { selling conflict } \\
\text { diamonds. } \\
\text { To reject the } \\
\text { Kimberley } \\
\text { Process would } \\
\text { limit ones } \\
\text { clientele to the } \\
\text { black market. }\end{array}$ & NONE & $\begin{array}{l}\text { Note that resolutions } \\
\text { passed under Section } \\
\text { VI of the UN charter } \\
\text { are not enforceable } \\
\text { but public outrage } \\
\text { forced the industry } \\
\text { into action. } \\
\text { Countries, not } \\
\text { companies, are } \\
\text { charged with the } \\
\text { enforcement of the } \\
\text { Kimberley Process. } \\
\text { However, the WDC } \\
\text { and the civil society } \\
\text { groups contribute to } \\
\text { the effective } \\
\text { implementation and } \\
\text { monitoring of the } \\
\text { Scheme. } \\
\text { KP Participants (43 } \\
\text { including the EU) } \\
\text { account for } \\
\text { approximately } 99.8 \% \\
\text { of the global } \\
\text { production of rough } \\
\text { diamonds. }\end{array}$ \\
\hline
\end{tabular}

\footnotetext{
${ }^{25}$ Chidester, Robert C., "Self-Regulation within the Diamond Industry: Case Study with a Focus on the Kimberley Process and Conflict Diamonds,” case study commissioned by PNNL, June 2005.
}

${ }^{26}$ www.kimberleyprocess.com

27 Ibid. 
TABLE 2-Fertilizer Industry Self-Regulation Approach

\begin{tabular}{|c|c|c|c|c|c|}
\hline Industry & $\begin{array}{c}\text { Triggering } \\
\text { Event/Context }\end{array}$ & Implementing Entity & Incentives to Join & $\begin{array}{c}\text { Disincentives to } \\
\text { Join }\end{array}$ & Comments \\
\hline $\begin{array}{l}\text { Fertilizer }^{\mathbf{2 8}} \text { - } \\
\text { (Trade [domestic } \\
\text { and international] } \\
\text { and physical } \\
\text { security of } \\
\text { materials } \\
\text { example) } \\
\text { International } \\
\text { Fertilizer Industry } \\
\text { Association (IFA) } \\
\text { European } \\
\text { Fertilizer } \\
\text { Manufacturers } \\
\text { Association } \\
\text { (EFMA) } \\
\text { The Fertilizer } \\
\text { Institute (TFI) }\end{array}$ & $\begin{array}{l}\text { Bombing of the } \\
\text { Alfred P. Murrah } \\
\text { Federal Building in } \\
\text { Oklahoma City } \\
\text { using ammonium } \\
\text { nitrate (fertilizer } \\
\text { and nitromethane } \\
\text { (volatile racing } \\
\text { fuel)) killing } 168 \\
\text { people in } 1995 . \\
\text { Bali nightclub } \\
\text { attack in } 2002 \\
\text { using ammonium } \\
\text { nitrate } \\
\text { World Trade } \\
\text { Center attack using } \\
\text { ammonium nitrate } \\
\text { in } 1993 \\
\text { Environmental } \\
\text { concerns of the } \\
\text { public }\end{array}$ & $\begin{array}{l}\text { Private (NGO) / public } \\
\text { partnership -- to agree on safety } \\
\text { measures regarding ammonium } \\
\text { nitrate. NGOs are: } \\
\text { 1. EFMA - advocates lowering } \\
\text { manufacturing emissions and } \\
\text { improved energy efficiency. } \\
\text { Has "Product Stewardship” } \\
\text { which deals with stricter safety } \\
\text { regulations, } \\
\text { 2. IFA-promotes fertilizer to } \\
\text { benefit the environment (joint } \\
\text { work with UNEP) + increase } \\
\text { energy efficiency + cleaner } \\
\text { production goals., } \\
\text { 3. TFI started campaign in } 2004 \\
\text { “American's Security Begins } \\
\text { with You” -- urges those who } \\
\text { handle ammonium nitrate to } \\
\text { implement security plans, keep } \\
\text { records of transactions, and alert } \\
\text { authorities of suspicious activity; } \\
\text { those who purchase it must } \\
\text { display govt. issued picture ID. } \\
\text { TFI has desire to preserve the } \\
\text { sustainability of fertilizer } \\
\text { products (environmentally } \\
\text { friendly and safe). }\end{array}$ & $\begin{array}{l}\text { 1. Access to information (each } \\
\text { NGO has its own databases } \\
\text { of statistical reports, } \\
\text { publications, industry and } \\
\text { safety benchmarking, new } \\
\text { technology developments) } \\
\text { 2. Close ties with govt officials } \\
\text { who influence regulations } \\
\text { (domestic and international); } \\
\text { TFI handles casework for } \\
\text { members (influences UN) } \\
\text { 3. Work together to influence } \\
\text { policy for entire industry; } \\
\text { new companies seek them } \\
\text { out to stay current. } \\
\text { 4. Run background checks and } \\
\text { allowing only those who run } \\
\text { legitimate businesses to sell, } \\
\text { purchase, and transport } \\
\text { fertilizer = public safer and } \\
\text { less govt. intervention (ban } \\
\text { on products) } \\
\text { 5. Self-regulation creates an } \\
\text { advantage at the corporate } \\
\text { level of a company because } \\
\text { of setting higher standards } \\
\text { than its competition; but for } \\
\text { NGO members, self- } \\
\text { regulation creates a level } \\
\text { playing field. }\end{array}$ & $\begin{array}{l}\text { Loss of independent } \\
\text { decision-making: } \\
\text {-Smaller companies } \\
\text { reap less benefits } \\
\text { because they have } \\
\text { less influence. } \\
\text {-Participating } \\
\text { companies have to } \\
\text { abide by their NGO } \\
\text { decisions. }\end{array}$ & $\begin{array}{l}\text { Goals - to improve and } \\
\text { regulate fertilizer quality, } \\
\text { safety, and production to } \\
\text { maintain and expand the } \\
\text { market. } \\
\text { Lack of government } \\
\text { regulations historically, } \\
\text { until recently no } \\
\text { regulations making it more } \\
\text { difficult to obtain } \\
\text { ammonium nitrate. } \\
\text { Industry has gained public } \\
\text { support and more business } \\
\text { by taking this proactive } \\
\text { step. }\end{array}$ \\
\hline
\end{tabular}

\footnotetext{
${ }^{28}$ Wyman, Charles, “Self-Regulation within the Fertilizer Industry: Focusing on Ammonium Nitrate Regulations,” case study commissioned by PNNL, June
} 2005. 
TABLE 3-Cement I ndustry Self-Regulation Approach

\begin{tabular}{|c|c|c|c|c|c|}
\hline Industry & $\begin{array}{c}\text { Triggering } \\
\text { Event/Context }\end{array}$ & $\begin{array}{l}\text { Implementing } \\
\text { Entity }\end{array}$ & Incentives to Join & $\begin{array}{c}\text { Disincentives to } \\
\text { Join }\end{array}$ & Comments \\
\hline $\begin{array}{l}\text { Cement- } \\
\text { Cement } \\
\text { Industry } \\
\text { Sustainability } \\
\text { Initiative } \\
\text { (Physical } \\
\text { security of } \\
\text { materials } \\
\text { example) }\end{array}$ & $\begin{array}{l}\text { The Bruntland } \\
\text { Commission (UN } \\
\text { Commission on } \\
\text { Econ. Development) } \\
\text { defined sustainability } \\
\text { Climate change } \\
\text { discussions and } \\
\text { Kyoto Protocol } \\
\text { meetings } \\
\text { Industry knew that it } \\
\text { was a large } \\
\text { contributor to } \mathrm{CO}_{2} \\
\text { emissions. }\end{array}$ & $\begin{array}{l}\text { NGO - } 16 \text { companies } \\
\text { are currently } \\
\text { members of the } \\
\text { initiative making up } \\
\text { two-thirds of the } \\
\text { world's production of } \\
\text { cement outside of } \\
\text { China. }\end{array}$ & $\begin{array}{l}\text { - Speaking with one voice to their } \\
\text { stakeholders (regulators, consumers, } \\
\text { shareholders, employees, and neighbors) } \\
\text { to stress their commitment to sustainable } \\
\text { development principles (e.g., publicize } \\
\text { their baseline } \mathrm{CO}_{2} \text { emissions and other } \\
\text { substances (dioxins and VOCs) and } \\
\text { report on them annually, publish targets } \\
\text { and progress, publicly report health and } \\
\text { safety information, communicate } \\
\text { rehabilitation plans for quarries and sites, } \\
\text { publish a statement of business ethics, } \\
\text { establish a systematic dialogue process } \\
\text { with stakeholders to understand and } \\
\text { address their expectations, report process } \\
\text { on developing stakeholder engagement } \\
\text { programs, develop documented and } \\
\text { auditable environmental management } \\
\text { systems at all plants, track the } \\
\text { performance of the industry and produce } \\
\text { full progress report after } 5 \text { years, and an } \\
\text { interim report after } 3 \text { years) } \\
\text { - Improved public image } \\
\text { - Improved environmental conditions } \\
\text { - Increased business performance and } \\
\text { higher profits. }\end{array}$ & $\begin{array}{l}\text { Complex and } \\
\text { challenging } \\
\text { coordination and } \\
\text { consensus building } \\
\text { among diverse } \\
\text { players } \\
\text { Loss of } \\
\text { independent } \\
\text { decision making, } \\
\text { particularly for } \\
\text { small companies } \\
\text { (difficult for small } \\
\text { companies to have } \\
\text { a substantial voice } \\
\text { on issues) }\end{array}$ & $\begin{array}{l}\text { Ten cement companies } \\
\text { commissioned the World } \\
\text { Business for Sustainable } \\
\text { Development (WBCSD) } \\
\text { to assess sustainable } \\
\text { development of the } \\
\text { industry, and to provide a } \\
\text { vision and } \\
\text { recommendations (1999) } \\
\text { Battelle conducted the } \\
\text { assessment - Toward a } \\
\text { Sustainable Cement } \\
\text { Industry }{ }^{29} \text { (2002) } \\
\text { Industry published } \\
\text { Agenda for Action (2002) } \\
\text { Industry issued progress } \\
\text { report (2005) } \\
\text { Bigger companies } \\
\text { working with smaller } \\
\text { companies to "bring them } \\
\text { along” and improve their } \\
\text { operations to help public } \\
\text { image of the industry. }\end{array}$ \\
\hline
\end{tabular}

\footnotetext{
${ }^{29}$ Battelle, “Towards a Sustainable Cement Industry: A Blueprint for the Future,” an independent study commissioned by the World Business Council for Sustainable Development,” 2002. The author, Gretchen Hund, participated in this three-year study. The reports can be accessed from www.wbcsdcement./final_reports.asp
} 
TABLE 4-Chemical Industry Self-Regulation Approach

\begin{tabular}{|c|c|c|c|c|c|}
\hline Industry & $\begin{array}{c}\text { Triggering } \\
\text { Event/Context }\end{array}$ & $\begin{array}{c}\text { Implementing } \\
\text { Entity }\end{array}$ & Incentives to Join & $\begin{array}{c}\text { Disincentives to } \\
\text { Join }\end{array}$ & Comments \\
\hline $\begin{array}{l}\text { Chemical - } \\
\text { International } \\
\text { Council of } \\
\text { Chemical } \\
\text { Associations } \\
\text { (ICCA) -- } \\
\text { Responsible } \\
\text { Care } \\
\text { (Physical security } \\
\text { of materials } \\
\text { example) }\end{array}$ & $\begin{array}{l}\text { Bhopal accident, cost of } \\
\text { environmental protection } \\
\text { estimated at over } \\
\$ 200 \text { B/year }\end{array}$ & $\begin{array}{l}\text { Unilateral Agreement - } \\
\text { NGO }\end{array}$ & $\begin{array}{l}\text { 1. Process } \\
\text { improvement and } \\
\text { cost reduction; } \\
\text { (e.g., P\&G claims } \\
\text { \$100M/yr saved for } \\
\text { last } 6 \text { years) } \\
\text { 2. Pre-empting } \\
\text { threatened } \\
\text { regulations } \\
\text { 3. Avoiding consumer } \\
\text { boycotts } \\
\text { 4. Influencing } \\
\text { inevitable } \\
\text { regulations } \\
\text { 5. Deflecting } \\
\text { monitoring and } \\
\text { enforcement }\end{array}$ & NONE & $\begin{array}{l}\text { Guiding principles with the goal } \\
\text { of improving the chemical } \\
\text { industry's communication and } \\
\text { transparency regarding its } \\
\text { activities and achievements, as } \\
\text { well as its health, safety, and } \\
\text { environmental performance over } \\
\text { time. Membership to the ICCA } \\
\text { requires companies to implement } \\
\text { Responsible Care. The website } \\
\text { is www.icca-chem.org. }\end{array}$ \\
\hline
\end{tabular}

\footnotetext{
${ }^{30}$ Lyon, Thomas P. and John W. Maxwell, “Voluntary Agreements for Environmental Protection,” (January 1999). http://ssrn.com/abstract=147888.
} 


\section{APPENDIX B}

\section{TABLE 1-Existing Nuclear I ndustry Organizations (I NPO and WANO)}

\begin{tabular}{|c|c|c|c|c|c|}
\hline Industry & Triggering Event/Context & $\begin{array}{l}\text { Implementing } \\
\text { Entity }\end{array}$ & Incentives to Join & $\begin{array}{c}\text { Disincentives } \\
\text { to Join }\end{array}$ & Comments \\
\hline $\begin{array}{l}\text { Nuclear Power } \\
\text { (Physical security } \\
\text { of materials } \\
\text { example) } \\
\text { Institute of } \\
\text { Nuclear Power } \\
\text { Operations-U.S. }\end{array}$ & $\begin{array}{l}\text { INPO: The nuclear electric utility } \\
\text { industry created the Institute of Nuclear } \\
\text { Power Operations (INPO) in } 1979 \text { (post } \\
\text { Three Mile Island). INPO's mission is to } \\
\text { promote the highest levels of safety and } \\
\text { reliability - to promote excellence - in the } \\
\text { operation of nuclear electric generating } \\
\text { plants.After the accident at the Chernobyl } \\
\text { nuclear power plant in 1986, nuclear } \\
\text { operators world-wide realised that the } \\
\text { consequences had an effect on every } \\
\text { nuclear power plant and international } \\
\text { cooperation was needed to ensure that } \\
\text { such an accident can never happen again. }\end{array}$ & $\mathrm{NGO}$ & $\begin{array}{l}\text { 1. INPO: } \\
\text { 2. Sharing of commercial industry } \\
\text { operating experience and data (lessd } \\
\text { learned) } \\
\text { 3. Copies of INPO Guidelines, Good } \\
\text { Practices and periodicals } \\
\text { 4. Limited attendance at industry-wide } \\
\text { workshops and conferences } \\
\text { 5. On-site special assistance visits } \\
\text { 6. Participation in training courses at } \\
\text { INPO's offices } \\
\text { 7. Access to INPO's Nuclear Network, } \\
\text { secure web site }\end{array}$ & & $\begin{array}{l}\text { There is an } \\
\text { INPO/DOE } \\
\text { contract where } \\
\text { DOE has } \\
\text { access to } \\
\text { certain INPO } \\
\text { products and } \\
\text { services }\end{array}$ \\
\hline $\begin{array}{l}\text { World } \\
\text { Association of } \\
\text { Nuclear } \\
\text { Operators }\end{array}$ & $\begin{array}{l}\text { WANO was formed in May } 1989 \text { by } \\
\text { nuclear operators world-wide. }\end{array}$ & NGO & $\begin{array}{l}\text { WANO: } \\
\text { Uniting to exchange operating } \\
\text { experience in a culture of openness, } \\
\text { so members can work together to } \\
\text { achieve the highest possible } \\
\text { standards of nuclear safety. } \\
\text { The culture of openness allows each } \\
\text { operator to benefit and learn from } \\
\text { others' experiences, challenges and } \\
\text { best practice, with the ultimate goal } \\
\text { of improving nuclear plant safety, } \\
\text { reliability and performance levels for } \\
\text { the benefit of their customers } \\
\text { throughout the world. }\end{array}$ & & \\
\hline
\end{tabular}


TABLE 2-Existing Nuclear Industry Organizations (WNA)

\begin{tabular}{|c|c|c|c|c|c|}
\hline Industry & $\begin{array}{c}\text { Triggering } \\
\text { Event/Context }\end{array}$ & Implementing Entity & Incentives to Join & $\begin{array}{c}\text { Disincentives } \\
\text { to Join }\end{array}$ & Comments \\
\hline $\begin{array}{l}\text { Nuclear Power } \\
\text { (Physical security } \\
\text { of materials } \\
\text { example) } \\
\text { World Nuclear } \\
\text { Association } \\
\text { To inform public } \\
\text { debate about } \\
\text { energy needs and } \\
\text { how nuclear } \\
\text { power needs to be } \\
\text { increased given } \\
\text { climate change } \\
\text { issues. } \\
\text { To provide } \\
\text { information } \\
\text { services to m } \\
\text { embers, } \\
\text { policymakers, the } \\
\text { media and the } \\
\text { public. }\end{array}$ & $\begin{array}{l}\text { Note mentioned on } \\
\text { the website, but } \\
\text { likely post } \\
\text { Chernobyl as well. }\end{array}$ & $\begin{array}{l}\text { NGO } \\
\text { WNA has 'Independent } \\
\text { Affiliates' comprise diverse } \\
\text { nuclear-related organizations } \\
\text { partnered with WNA. These } \\
\text { are: } \\
\text { - professional organizations } \\
\text { with an international } \\
\text { membership and a specific } \\
\text { focus of interest; } \\
\text { • national or regional } \\
\text { commercially-based } \\
\text { membership organizations; } \\
\text { • national nuclear societies; } \\
\text { and } \\
\text { • citizens' organizations } \\
\text { supporting nuclear power as a } \\
\text { key clean energy option. }\end{array}$ & $\begin{array}{l}\text { United voice working } \\
\text { towards increasing } \\
\text { nuclear power operations } \\
\text { worldwide. } \\
\text { To share information and } \\
\text { develop analysis on a } \\
\text { range of technical, trade } \\
\text { and environmental } \\
\text { matters. These subjects } \\
\text { include: } \\
\text { - nuclear fuel production } \\
\text { and industry } \\
\text { economics } \\
\text { - nuclear trade issues } \\
\text { - radiological protection } \\
\text { - 'nuclear event' } \\
\text { definition } \\
\text { - transport } \\
\text { - waste management and } \\
\text { decommissioning. }\end{array}$ & & $\begin{array}{l}\text { WNA Charter of Ethics*: } \\
\text { Principles: “Our strong support } \\
\text { for the work performed - By } \\
\text { governments, through the } \\
\text { International Atomic Energy } \\
\text { Agency (IAEA), to promulgate } \\
\text { nuclear safety standards for the } \\
\text { worldwide nuclear industry and } \\
\text { to ensure that there has been } \\
\text { no spread of nuclear weapons } \\
\text { arising from the civil nuclear } \\
\text { fuel cycle. } \\
\text { The WNA is concerned with } \\
\text { nuclear power generation and all } \\
\text { aspects of the nuclear fuel } \\
\text { cycle, including mining, } \\
\text { conversion, enrichment, fuel } \\
\text { fabrication, plant manufacture, } \\
\text { transport, and the safe } \\
\text { disposition of spent fuel. } \\
\text { On the public website, the } \\
\text { Secretariat's aim is to maintain } \\
\text { the best available non-technical } \\
\text { source of information on the } \\
\text { global nuclear industry. }\end{array}$ \\
\hline
\end{tabular}




\section{* From the WNA Charter of Ethics}

The WNA calls for its member participants to abide by the following principles:

- International Legal Obligations -“Our individual and common responsibility to uphold respective international legal commitments embodied in -

o The IAEA statute; safeguards agreements concluded pursuant to the Treaty on the Non-Proliferation of Nuclear Weapons; and regional and bilateral accords providing for IAEA verification;

o The Convention on Nuclear Safety; the Convention on the Physical Protection of Nuclear Material; the Convention on Early Notification of a Nuclear Accident; the Convention on Assistance in the Case of Nuclear Accident or Radiological Emergency; the Convention on the Prevention of Marine Pollution by Dumping of Wastes and Other Matter; and the Joint Convention on the Safety of Spent Fuel Management and the Safety of Radioactive Waste Management; and

o Other international treaties and conventions that contribute to ensuring the safe and peaceful use of nuclear technology throughout the world”. 


\section{PNWCGS Mission}

Our mission is to address the full range of global security issues by probing the impact of economic, social, institutional and environmental conditions that affect regional stability and global security. We emphasize non-proliferation due to its consequence for global sccurity.

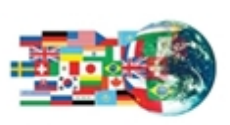

Pacific Northwest Center for

\section{Global Security}

For more information, contact:

Carol Kessler. Director

Pacific Northwest Center for Global Security

Pacific Northwest National Laboratory

1100 Dexter Avenue North, Suite 400

Seattle, WA 98109

Phone: 206-528-3222

Fax: 206-528-3225 